\title{
Discrepancy of Graham Greene
}

\author{
Parastoo Asgharpur \\ E-mail: p.asgharpur@gmail.com
}

Received: 18-12-2012

Accepted: 24-02-2013

Published: 01-05-2013

doi:10.7575/aiac.ijalel.v.2n.3p.10

URL: http://dx.doi.org/10.7575/aiac.ijalel.v.2n.3p.10

\begin{abstract}
Lack of religious sense in twentieth century made so many writers to object to the situation. One of these writers who had devoted a very challenging criticism to himself is Graham Greene. In criticizing Greene's novels there has always been an argument that Is there any relationship between his novels and his personal life? In this article the role of Catholicism Graham Greene's works and his own personal life has been examined. In order observe such a role we need a very detailed examination of Greene's life, his personal letters, his conversations and his works. According to so many critics the close relationship between Greene's life and his works is not ignorable. So by applying Biographical Criticism on Graham Greene it is obvious that about this writer the death of author does not work. The prominent figure of the writer seems to be present in each story and each action.
\end{abstract}

Keywords: Greeneland, Graham Greene, Biographical Criticism, Morality, Catholicism, Twentieth century Catholic novel.

\section{Introduction}

One of the important issues discussed in twentieth century literature was religion and its role in literature. The religion which for so many years has dominated the literature of England was now underestimated by so many writers. Except a few number of writers such as T.S.Eliot, Evelyn Waugh and Graham Greene the works of other writers seemed to lack as Greene puts it "the sense of humanity". T.S.Eliot with his religious poems and treaties was one of the famous figures in this century who defended religion and religious doctrines. In most of his poems he put the immoral condition of the century under investigation and tried to instruct and teach through his writing. The next writer to whom this article is mostly dedicated is Graham Greene and his strange fame as a religious writer. It was in the twentieth century that Graham Greene objected to the lack of moral values in English Literature. He puts his objection as following:

"After the death of Henry James a disaster undertook English novel... for with [his] death the religious sense was lost to the English novel, and with the religious sense went the sense of importance of the human act, it was as if the world of fiction had lost a dimension: the characters of such distinguished writers as Mrs. Virginia Woolf and Mr. E.M. Forster wandered like cardboard symbols through a world that was paper thin." (Graham Greene, 1980, p. 91)

These lines are told by a writer who in his own words happens to be a Catholic writer. He has objected to the lack of religious sense in this century, but in this research it is observable that by studying Greene's life story and works, his own characters and his own created world, called Greeneland by other critics, and even Greene's most religious characters seem to be wandering like cardboard symbols through a world that is paper thin. In order to study the role of Catholic in his novels and to find the reason for the changes that happened in his writing career, it is necessary to have a survey on Graham Greene's personal life and its important events. Although the Biographical approach was condemned by so many critics in this century, but the existing evidence in his novels shows that his life and his ideas cannot be separated from them. The childhood experiences of Greene, his conversion to Catholicism, and his love affairs in his late ages cannot be ignored in the process of his novel writing.

Whenever encountering Graham Greene, the critics discuss the pattern present in his works. He has started as a Catholic writer, writing so many religious novels with strong religious content but he ends in political and social novels. There have been many investigations on this issue; many have stated that Greene became non-religious at the last years. Others have rejected such an idea and claim that Greene had got a new perspective of life at his adult age and he hasn't forgotten about religion. The latter critics believe that Greene has changed his perspective from the rigid rules of morality to more tangible and practical ones. Mark Bosco S.J., 2005, one of these critics, concludes studying Greene like this:

"Greene never liked being called a Catholic novelist, he was more content with the title "Christian humanist". His fiction like all good literature tended to encourage readers to acknowledge and attend to the humanity of other human beings, to enter a fictional world in order to experience "the heart of the matter" about human life or "the human factor" in the mystery of political events. Yet many critics have questioned whether Greene's humanism is all that Catholic. They contend that he became more secularized later in life, arguing that his later novels reduce religious belief to such an extent that only the aura of belief remains. Greene diminishes the institutional and rationalized side of Catholic belief, not to rid himself of it, but to make clear that it is the practice of faith, hope, 
and love- and primarily a faith, hope, and love that costs the individual something-that makes possible belief in a God present in the world." (p.157)

This study by focusing on Greene's own life, important events in his life, his letters and conversations will show that even in his own life he have had such a change. At first being very religious maybe because of his love toward a Catholic girl, and later more secularized. So this problem is related to his own personal life and affairs. The objectives of the study would be first to solve this discrepancy existing in Greene's work, second to have a survey to show that how an author's personal life can have direct effect on his works. So this research is a kind of Biographical approach to investigate the events affecting Greene's work. So the main question of this thesis revolves around Greene's personal religion and life and its effect on his novels. The researcher tries to answer questions like

Is the Catholicism stable through all Greene's works? And

Is there a relationship between Greene's life and his literary works?. How can a text reflect its author and how much is biographical criticism applicable to Greene.

In his book "Graham Greene's Catholic Imagination" Mark Bosco. S. J. has discussed the Catholicism existing in Graham Greene's work and the role of such Catholicism in his novels.

He has started with describing Greene's Catholic pattern, he notes that:

"If Catholicism is not the very fabric of many of these texts, it is always a thread that helps to bind his literary preoccupations into a recognizable pattern", but there exists a problem "Greene's unorthodox treatment of orthodox ideas raised ambiguities and made it difficult to definitively clarify his attitude" ( $p .3)$

After introducing such a problem about Greene, Bosco.S.J. moves further to investigate the origin of Catholic genre in English literature and in his idea:

"With the novels of Evelyn Waugh and Graham Greene, the Catholic genre found a popular preeminence in England in the 1930s and 1940s." (p.8)

Bosco.S.J.,2005, speaks about other critics' ideas about Greene's religion: David Pryce-Jones's 1963 study, which looks almost exclusively at the religious aspects of Greene's texts, reproaches

his use of Catholicism as merely a clever tactic on the author's part to super impose paradoxical situations into his melodramas" (p.10)

John Atkins complains in his 1957 comprehensive study that the constant attention paid to Catholicism and theology obscures the more important literary themes and issues, noting thatn "Greene's work is valuable as social commentary and much more as individual (including persona) revelation ... the revelation is on the surface,planted there rather weightily but it is a surface growth" (p.10)

He continues talking about different criticisms of Greene's religious writings, their doubt about his faith being real or production of a personal trauma, his characters and their psychological and moral crisis, and others who took Greene to task for obscuring his humanism with religious tension.

His concluding remark is as follows:

"It is true that after Greene's publication of A Burnt- Out Case in 1961, he extricated himself from the stylistic intensity of his characters Catholic interiority as the primary focus for formulating the crises in his novels, whether a character's actions contributed to his personal salvation or damnation was no longer the paramount issue in his novels; rather Greene's focus turned to human action deriving from political relationships that allegorized the human struggle in economic and moral terms. Most criticism has seen this as a "post-Catholic" maneuver on Greene's part, a turn away from the imaginative world of Catholicism. Yet Greene's artistic confrontation with his religious imagination parallels the developments in Catholic theology, doctrine, and liturgy since Vatican 11.

When Greene returns to explicitly religious themes in his late novels, he is not merely reworking the conflict of his previous " Catholic cycles", but is also engaged in a dialogue with the political concerns, as well as the religious crises, of belief that have become part of the experience of Catholicism since the end of the council." (p.23)

So the discrepancy existing in Greene's work according to Bosco does not show that he has changed his beliefs or has become a heretic, but Catholicism in his later novels is a part of a dialogue with the contemporary situations of his texts. Greene didn't want to get rid of Catholicism but to make clear that it is the practice of faith, morality, love and etc. which means belief in God. So his developed literary aesthetic is not post-Catholic or post-Christian but Catholic and post-Vatican 11.

In another study "Graham Greene An Approach to his Novels" Robert Hoskins,1999,applies Biographical Criticism on Greene.

After discussing the characters of the first phase of Greene's work in a chapter called " The First Phase Protagonists and the Author", Hoskins tries to highlight the obvious relationship between Greene and his Characters:

"The characters are journalists like Greene himself, they undertake travels to foreign lands in search of meaningful experience and in flight from boredom as Greene had done in his youth and would continue throughout his life, and these characters are drawn, in spite of their natural proclivities and/or backgrounds toward a fascination with the Catholic religion. For some characters as for Greene himself this fascination is linked with the love of a young woman." (p.29) 
Then Hoskins continues by asserting that

"While it is always necessary to be cautious in reading backwards from the works to the life of any author, it is impossible not to see powerful elements of Greene's life and personality in the novels of the first phase. The obsessive themes of betrayal, divided loyalties, and the terror of life have long been noted by critics who, with some encouragements from the author, have traced the roots of those themes to Greene's childhood unhappiness and Berkhamsted School."

He also writes:

"The familiar themes of self- division and the insistent dichotomy Between sexual and spiritual love in the early works, for example have roots not only in the literary sources emphasized by Allott and Farris in their excellent early study of Greene, and not only in what is in some respects a familiar quality of youthful experience, but also in the circumstances of the author's own courtship and marriage" (p.33) as discussed by this writer Graham Greene had a kind of uncertainty, he wanted to have a highly spiritualized marriage and on the other hand he longed for traveling, excitement and taking risks. This led him to understand that he has not been made for such a marriage life. He fell in love with a Catholic girl called Vivien, whom he praised both physically and spiritually. She was as Greene calls her "The Philosopher's Stone" which purified baser materials like Greene himself. This girl had a profound effect in the ideology and life of Graham Greene. In his letters to her we can observe the passion and enthusiasm of Greene which finally led to his conversion to Catholicism.

A very conspicuous example which he refers to is Scobie in "The Heart of the Matter", a novel when Greene has written the book during a period of distress and he himself like Scobie has committed suicide during this period. Hoskins writes that during this period Graham starts a relationship with another woman while Vivien is away. And like his character Scobie, the prohibitions of the Church against adultery do not stop him from his actions. Another problem annoying Greene was the War; he didn't think that he would survive the war so he thought that his suicide would free him of such a dilemma.

But the condition became worse when he fell in love with another woman "Catherine Walston "who created a quadrangular relationship. Greene like Scobie in the story felt himself responsible about the two woman's happiness and felt that it is just death that makes him free of such condition. So it is clear that the unlike his own saying in his interview Greene most of the times is the identical with his characters.

In his book "Graham Greene's Narrative Strategies" Murray Roston, 2006, also discusses the idea of Biographical approach about Graham Greene.

He starts the discussion as this:

"Some relationship undoubtedly exists between an author's personal experiences and the literary creations; but biographers' attempt to trace fictional events to incidents in a writer's life are at all times fraught with danger, since in the process of displacement such experiences inevitably undergo distortion." (p.1)

In his idea Greene invites such linking of his fiction to past events within his own life. The setting of Greene's novels is also related to Greene's travel experiences. He had travelled a lot and his travels has provided the setting of so many of his novels such as: "The Heart of the Matter", "The Power and the Glory" and etc. This critic draws our attention to Greene and his reluctance for interviewing and concludes that because of such a characteristic in Greene we cannot trust what he says in his interviews, so it is better to follow his texts and from the text itself we must deduce the ideas in Greene's mind. He uses Hans Jauss's approach that an innovative writer, aware of the reader's ' horizons of expectation'_ whether they be moral, philosophical, social, or aesthetic- must attempt to overcome them, to wean the reader away from them towards new or modified values.

\section{Graham Greene's life story and important events}

Henry Graham Greene is born on 2 October 1904 in Berkhamsted, Hertfordshire. Among his first words are ' poor dog', a reference to his sister's dead pug that had been run over by a carriage and carried home lying at baby Graham's feet in his pram. He is the son of Charles Henry Greene, later to become the headmaster of Berkhamsted school (1910-27), and Marion Raymond Greene, first cousin of one of Greene's early literary heroes, Robert Louise Stevenson. Greene himself is the cousin of another of the century's major writers, Christopher Isherwood.

He is the fourth of six children, and the third of four boys who will grow into very tall men. His younger brother is Hugh, to whom he is very close and who will achieve eminence as the director-general of the BBC (1960-69). His elder brother is Raymond, his father's favorite, school prefect, and Head of House, who will go on to be a distinguished doctor. His eldest brother is Herbert- according to Graham, the black sheep of the family and who is the model for the feckless and irresolute Anthony Farrant character in England made Me (1935).

At the age of fourteen he becomes the boarder at Berkhamsted School. The effect is traumatic: he is bullied and finds himself torn between loyalty to his father, on one side of the green baize door that separates home from school, and loyalty to his school friends who rebel against the school's authority. Greene will come to believe that the key theme of ' divided loyalties' in his work derives from this youthful experience."

The school brings so many mental problems for Greene that he has to go near a psychiatric called Dr. Kenneth Richmond who suggest Greene to write and free himself from the tensions of reality. The most significant outcome of 
this era can be his autobiographical books, which later became the source of so many of his novels. Committing suicide, boredom of life, involving in love affairs and so many other activities were conspicuous in Greene's life.

One of the most important events in Graham Greene's life was his studying in the Berkhamsted School, where his father was a boarder and it had a traumatic effect on him. He always relates the divided selves in his novels as a result of a duality existing in his life in these years. His loyalty was divided between his father and his friends in the school.

The second important event in Greene's life was his conversion to Catholicism. When he was working in the newspaper as an editor, he received a letter from a Catholic woman Vivien Dayrell Browning and this letter was the cause of their first meeting. Graham Greene fall in love with this girl and even converted to Catholicism, although he has stated that his conversion was both emotional and intellectual.

His religion is most of the time debated by the critics, they believe that his Catholicism has had a great effect on his works. He converted to Roman Catholicism because of his love toward Vivien Dayrell Browning; of course he has many times stated that his conversion was both emotional and intellectual. In his book Graham Greene's Imagination Mark Bosco.S.J.,2005, writes that Greene wavered between belief and disbelief most of his life, and he often spoke of it in unconditional statements, as in a late interview:

"If there is a God, the Catholics probably come nearest to getting him right." ${ }^{7}$ This probability brings a kind of dilemma in most of his novels. We clearly notice the effect of Newman's thought in these works. All Greene's characters are in difficult situations, they have a struggle with their faith in "dangerous edge of things."

So putting characters, mostly Catholic ones, in a difficult and challenging situation in order to examine their faith and choose the best way is what Greene wants to show. Many critics have accused Graham Greene of being a heretic writer or misusing Catholicism in order to give an importance to his novels. But it is better to accept the idea that he loved to put his characters in the heart of danger in order to choose between belief or disbelief. So if the characters, even the most religious ones choose to be in the evil's part they may be right.

This can be the reason why Graham Greene himself is in the devil's party, or why did he sympathizes with sinners? He thinks that these people are right even by choosing wrong actions.

Newman's outlook is found throughout Greene's narrative world, for like Newman he accepts the ontological and metaphysical existence of evil as a fact of life, as the" way of the world". (p. 25).

Graham Greene in his interviews with Marrie Allain says that he became a Catholic because he needed conviction that God existed. He says that religion bored him with Sunday services and its endless readings from the Bible. He also explains that he converted to Catholicism because he wanted to know what his wife believed. He believed in God not as absolute but as a provisional one, he chose the name Thomas to identify himself with Thomas Didymus, the doubter not St Thomas Aquinas.

These novels are from different periods in Greene's life in order to see that what had happened in each stage of his career. As critics of Greene always divide his novels to two categories of Catholic and post- Catholic novels, this selection has tried to select the novels in which this division is more conceived. One reason of selection was this and then these novels were supposed to have made great changes in Greene's career of writing. The first "Brighton Rock" opened a new version in his works called Catholic novels. The second "The Heart of the Matter" was so challenging in Greene's novels because of its dealing with such topics as suicide, adultery, and pity. And the third one discussed here is "The Quiet American", revealing Graham Greene's abhorrence toward America. The idea that Greene's late novels are changed in content and even structure (Greene himself has stated that his style at "The Quiet American" and the novels after has become simpler) has been discussed a lot and to a great extent can be related to author's own changes in religious and political views and even whole humanity.

In these three novels the focus of the study will be on the important quotations which may reveal the author, the religious ideology undergoing them, and the setting of these novels and its relationship to Greene's travels.

Graham Greene's novels

The first novel chosen here is "Brighton Rock" which is supposed to be his most religious book.

Mark Bosco.S.J. introduces this book as a book which launched Greene into the category of Catholic novelist.

In this book's introduction Greene writes that:

"Brighton Rock began as a detective story and continued, I am sometimes tempted to think as an error of judgment. Until I published this novel I had like any other novelist been sometimes praised for a success and sometimes condemned with good enough reason as I fumbled at my craft, but now I was discovered to be -detestable term! A Catholic Writer"(Graham Greene, 1977)

Brighton Rock is supposed to be Greene's most religious novel as he himself once mentioned

"I had become a Catholic in 1926, and all my books, except for one lamentable volume of verse at Oxford, had been written as a Catholic but no one had noticed the faith to which I belonged before the publication of Brighton Rock."

This novel has also been described by so many other critics such as Michael G. Brennan (2011):

"Brighton Rock is a culmination of many of Greene's paradoxical thoughts during the ten years since his conversion to Catholicism about the malignant potency of the fallen world, the often mundane guises of good and evil and the ineffable nature of Devine Mercy." 
This novel was considered to make a turning-point in Greene's career in its exploration of the nature of evil.

The important characters that we deal with in this novel are Ida Arnold who is described as this:

"She wasn't religious. She didn’t believe in heaven or hell",(BR P: 40)

in another part Ida herself says

" I believe in right and wrong." (BR Page 57)

" I don't want the innocent to suffer"(BR page 149).

She is concerned about right and wrong, she believes in rational idea that life is for living to the full since nothing follows it. She reassures herself with a specifically anti-Catholic thought: 'Let Pappists treat death with flippancy: life wasn't so important perhaps to them as what came after: but to her death was the end of everything.(P 50, Graham Greene Fiction Faith Authorship)

And two other characters Pinkie and Rose who believe in good and evil, and do not want to change their Catholic ideas towards hell and heaven.

Being Catholics, they believe by their illegal marriage they are committing a mortal sin and they are never going to be forgiven.

Pinkie's belief is revealed during this conversation:

"But you believe, don't you? Rose implored him," you think it's true?"

"Of course it's true," the Boy (Pinkie) said.

What else could there be? He went scornfully on" why?" he said" it's the only thing that

fits. These atheists, they don't know nothing. Of course there's Hell. Flames and damnation.

"and Heaven too," Rose said with anxiety.

"Oh maybe," the Boy said, "maybe"

So it is obvious that Pinkie is a Roman who believes mostly in Damnation and Hell but again does so many mortal sins. In one part of the novel he says "you don't want to listen too much to priests, they don't know the world as I do, the ideas change, the world moves on"

(BR page 172).

One important part of the novel can be "appalling... strangeness of the mercy of God". Even a character like Pinkie who is damned can be saved .Rose loves to be damned because the boy that she loves is damned. So at the end of the novel the priest tells Rose that the Church never demands that we should consider any soul absolutely' cut off from mercy'..

So here we have this two characters who feel they have been damned and they don't believe in God's mercy to rescue them, but on the other hand we have the non-religious Ida with whom the author mostly sympathizes and believes that even the damned Rose can be rescued if she chooses to do the Right action and leave Pinkie alone. Greene sympathizes with Ida because he believes in the idea that God forgives every one and those committing sin are to be forgiven sooner than others because he thinks that God who is kind cannot destroy human beings and send all to hell.

This novel is also discussed in an article titled " The Ambivalent Catholic Modernity of Graham Greene's Brighton Rock and The Power and the Glory" Karl O'Hanlon writes that 'the religious sense' emerged from Graham Greene's Catholicism provides the basis for the critique of the ethics of the modernity in his novels Brighton Rock (1938) and The Power and the Glory (1940). With the character Ida who concerns herself mostly about right and wrong and two other characters which concern themselves with the religious issue of good and evil. He considers the character Pinkie and his ideology somehow dangerous for the modern time.

And in another place mentions that:

" In Brighton Rock, Graham Greene explores the way in which Christian agape is substituted in modernity by, on the other hand, dutiful adherence to abstract, rational law, and on the other hand a subjectivist ethics based on sensibility."

\section{The Heart of the Matter}

This novel has been chosen to be investigated as second novel in this article because it is one of Greene's most famous novels and a novel which occupied a unique place in Graham Greene's fiction.

In his interview with Allain Marie- Francois, when Graham Greene is asked "when have you lapsed in your own eyes?"

Answers:

"I have perpetrated some bad books. I don't like The Heart of the Matter, though it was the start of my success, back in 1949"

"In The Heart of the Matter, a book which I dislike, Scobie is torn between pity and pride" (same book page 26) 
So many critics have tried to relate the character of Scobie to Greene himself telling that Scobie like Greene himself in the time of writing this book has sexual affairs with other woman, he like Scobie being tired of his life situation commits suicide and so many other similarities.

In the book" Graham Greene's Narrative Strategies",2006, it is discussed that why Greene sympathizes with such sinners as Scobie? The answer as it was told in previous sections may be because Greene believes that true faith is only achieved through doing something wrong and then repenting. He prefers not to speak about saints who see themselves as perfect entities and are in danger of committing an unforgivable sin, Pride. His idea is that the saints and priests must not just attend church, listen to confessions and etc. they must be situated in challenging circumstances in order not to dull their souls. Greene was not an anti-Catholic as some critics has put it, he encouraged a re-affirmation of Christian values. Scobie's pity toward the characters of the novel is one important issue discussed in many criticisms.

"Pity smoldered like decay at his heart. He would never rid himself of it. He knew from experience how passion died away and how love went, but pity always stayed. Nothing ever diminished pity. The conditions of life nurtured it. There was only a single person in the world who was unpitiable, oneself. (P. 178).

Pity had many bad effects on his life, it is on page 12 of this novel that we can notice the first sign of Scobie's pity and responsibility toward his wife Louise.

"He watched her through the muslin net. Her face had the yellow ivory tinge of atabrine: her hair which had once been the color of bottled honey was dark and stingy with sweat. These were the times of ugliness when he loved her, when Pity and responsibility reached the intensity of a passion"

Again in the scene that Scobie must search the captain's cabin he pities the captain and his little daughter whom the captain talks about. So he does not the letter that captain had written to his daughter to the authorities.

So little by little Scobie is destroying himself to help the others. After rejecting the presence of the illegal letter in Captain's bathroom he felt as the following:

"Scobie put his hand against his forehead and shivered: the sweat seeped between his fingers, and he thought, am I in for a touch of fever? Perhaps it was because his temperature had risen that it seemed to him he was on the verge of a new life. One felt this way before a proposal of marriage or a first time."

Michael G.Brennan in his book Graham Greene Faith Fiction and Authorship",2010, writes about the relationship of this novel to Greene's personal life that

"With the last third of The Heart of the Matter written after his infatuation with Catherine had begun, Greene's treatment of Scobie's marital dilemma focused on the psychological 'sin' of pity and its consequence, a fascination with the real Catholic sin of suicide as the only available release from personal crisis."

Another important scene in this novel is the famous scene in which Scobie bargains with God when encountering a dying child out of the shipwreck he implores "Father look after her, give her peace. Take away my peace forever, but give her peace."(The Heart of the Matter P: 106-107)

After this Scobie begins doubting and even rejecting the presence of God, he seems to be tired of his religion and claims that it leads him to nowhere and it cannot any more answer his question. So he confesses to Father Rank:

"I don't know how to put it, Father, but I feel tired of my religion. It seems to mean nothing to me. I've tried to love God, but I'm not sure that I even believe." (The Heart of the Matter P: 134) .

Or in next page :

"He feels empty, empty, he thought that there is nothing to absolve. He didn't feel anything about relief

"They were a formula: The Latin words husted together-A hocus pocus.".

This is debatable that to what extent these can be Greene's own ideas. Because as it was discussed before Greene himself had changed in the time of writing this novel, he has started some love affairs, and committed suicide.

After Louise's return Scobie feels himself responsible for two people and tries to make both of them happy. He does not any more want to attend the Confession and Communion. Because he has done adultery he thinks that he is in a state of mortal sin a so he can't go to the Church. But the most important issue here is "expressing a Greeneian paradox" Scobie even speculates that 'lack of Faith' allows him to see ' more clearly than faith' (page 88 Graham Greene's Faith fiction and Authorship). He does not any more feel calm and absolved even by confession; he just feels to be in a state of decay. So at the end he decides to committee suicide he justifies his action like this:

"if it is the worst crime for a Catholic, Scobie thinks, then 'it must be a perfect one' ( The Heart of the Matter)

But when he tries to kill himself he is in a state of doubt that whether he is going to be forgiven or damned forever.

It was as if the sacraments which had lodged there for his damnation gave tongue. You say you love me, and yet you'll do this to me- rob me of you forever... all you have to do now is ring a bell, go into a box, confess... the repentance is already there, straining at your heart.

Scobie himself thought that committing suicide is an unforgivable sin and leads to damnation and eternal Hell. But he feels that he cannot be free except killing himself, by doing so he can release his soul. When he ponders over doing such an action his justification is as the following: 
"No one needs the dead. The dead can be forgotten. O God, give me death before I give them (people around him) unhappiness.) (The Heart of the Matter P. 169).

Another important point in this is laid in the finishing part of it, when Father Rank and Louise debate about Scobie's suicide and his being forgiven or not.

When Louise says that " he was a bad Catholic", Father Rank answers:

-that's the silliest phrase in common use

- and at the end this -horror. He must have known that he was damning himself.

-yes he knew that all right. He never had any trust in mercy, except for other people. It's no good even praying...

Father Rank clapped the cover of the diary to and said furiously, for goodness sake Mrs. Scobie-don't imagine you or I -know a thing about God's mercy.

-the Church says...

- I know the Church says. The church knows all the rules. But it does'nt know what goes on in a single humane heart... I think from what I saw from him that he really loved God.

So this conversation can be considered as the turning point of this novel and Greene's ideas. He does not any more think that being a tough Catholic may lead to salvation and eternal peace. Here according to a Catholic Priest the sinful man are more close to God than the virtuous people. And God is going to forgive their sins and they are not damned to eternal fire. This idea is stated in this novel and needs consideration in Greene's own life. he himself in his life cared a lot about other people's happiness and even for their happiness he scarified himself.

\section{3-3 The Quiet American}

This novel is chosen to be investigated because it seems to be different from Greene's other works. The difference lies in the shift in the subject matter. Here Graham Greene unlike his previous works does not concern himself a lot with ethical and religious matters, and as Michael G. Brennane,2010, describes this novel:

"The Quiet American was completed in June 1955 and published in the United Kingdom in December 1955 and the USA in March 1956. Its alienated and geographically displaced anti-hero is a world-weary reporter called Thomas Fowler. He takes an existentialist pleasure in his disassociation from the society around him and adopts as his personal 'creed' the mantra: ' let them fight, let them love, let them murder. I would not be involved' (20) Bernard Bergonzi comments that in The Quiet American Greene finally 'decides to give God a rest', structuring it around a ' humanistic rather than a religious frame of reference'.(p.103-104)

This description of the novel can be considered as best description.

In another book called "Graham Greene and the politics of popular fiction and film" Brian Lindsay Thomson quotes Francis and Allote:

"Since the middle fifties, Greene has grown more secular, more revolutionary, more equivocal, and at times more frivolous, and so have many of his readers."

Like Greene himself Fowler is a journalist and works for magazine. Like Greene Fowler is hopelessly estranged from a devoutly religious wife, aand Fowler's Anti-Americanism that is typical of Greene.

In this book we can observe the change in viewpoint and subject matter. Here Graham does not speak about good or bad, right or wrong, or any other religious matter, his concern is mostly about politics. The most important topic is AntiAmericanism. The main character of the novel Fowler in some parts of the novel even denies the existence of God. He challenges a lot to show that humanism is more important than the belief in the existence of God.

On page 52 of this book a priest is described as following:

"There was something corrupt and cunning about him; the word love occurred often. I was certain he knew that all of us were there to laugh at his movements; our air of respect was as corrupt as of his phony hierarchy, but we were less cunning. Our hypocrisy gained us nothing -not even a reliable ally, while theirs had produced arms, supplies, even cash down."

Or in another part the narrator Fowler claims that:

"I had never desired faith. The job of a reporter is to expose and record. I have never in my career discovered the inexplicable."

Fowler's ideology is clearly stated in the following conversation with Pyle on page 59 he tells his friend Pyle that:

"I laugh at anyone who spends so much time writing about what doesn't exist—mental concepts."

Pyle:" They exist for him. Haven’t you got any mental concepts? God, for instance?"

Fowler: " I have no reason to believe in a God, do you?"

Pyle: "yes I am a Unitarian"

Reporter: "How many hundred million Gods do people believe in? Why even a Roman Catholic believes in a quiet different God when he's scared or happy or hungry"

Pyle: "Maybe. If there is a God, he'd be so vast he'd look different to everyone." 
Rather than being an indifferent atheist, Fowler is an individual who insistently seeks to reassure himself of the absence of a God in the world of humanity. (p.104) he regards death as the only absolute value and both envies and distrusts those who claim a belief in God.

So in this novel a character is created who unlike Greene's previous characters is not a believer and except some discussions of him and his friend, we do not observe a lot of religious debates in the novel. The main content of the novel seems to be political issues, but as Mark Bosco puts it:

"The Catholic Matrix of Greene's imagination is still unmistakably present even as political struggles and moral commitments to political situations displace the extreme religious dilemma of his characters." (p.72)

\section{Graham Greene's Conversations}

The following questions and answers are between Greene and Allain Marie, a daughter of one of his friends. Maybe it was because of such a relationship that Greene accepted to have an interview with her (Greene was very reserved and unwilling to have interviews during his life). In this book called "Conversations with Graham Greene: The Other Man"(1984), Marrie- Francois Allain asks many interesting and revealing questions from Graham Greene that the answers will help a lot to know about Graham Greene's characteristics.

Marrie's idea about Greene is stated like this:

Greene at all events remains obscure in his life, his work, his person. So he keeps his interlocutor or reader in a dilemma, hoping to discover him and yet reluctant to pursue a frustrating investigation. He is impressive, restless, and occasionally frivolous, subject to sudden tempers and to almost child-like enthusiasms. (P.13)

Allain starts her interview with a difficult question about Greene and his feeling about himself. She brings the Epigraph to The Man Within to trap Greene in difficult situation:

"There's another man within me that's angry with me"

Based on this Epigraph she asks Greene:

So you don't like yourself...?

In answer Graham Greene says No, but he explains that this is something normal and many people have such a problem with themselves and they are like him not at ease with themselves. And in Greene's idea this is not a fault. Greene continues saying that writing has worked as a therapy for him in order to cure himself and his psychological problems, and writing dream diaries has been the most effective one. He confesses that without writing he would have had problem in treating his mental problems. It is clear that the First World War has had many bad effects on Greene and it was because of these effects that he considered life to be a chaotic affair.

When Graham Greene heard that Norman Sherry has started to write a biography of him, he talks about him in this way:

"At this moment a person hitherto unknown to me, Norman Sherry, is busy writing my biography. The poor man! Terrible things keep happening to him as he goes wherever I've been. He dogs my footsteps. He's been to the same lost Mexican villages. He's caught dysentery in the very Mexican town where I caught it in 1938. He's gone to Liberia forty-five years after me, and in the very country where I almost died of fever, he barely avoided the revolution. He plans to go to the leper colony I visited in Congo in 1959. My experiences are certainly giving him plenty to do. I'm glad this biography is being written by a non-Catholic it will, I hope, be more objective." (P.17)

It is clear that how much difficult it is to write about one person's life and experiences, in order to feel what Greene had experienced Norman Sherry had to feel even Greene's feelings. He had to travel the countries he traveled and see the people he visited. So by these lines Greene is revealing the difficulties which he had experienced during writing process, in order to write a novel he had to travel to many countries, live with so many people ( even lepers), and observe the life and problems of the people in such countries. He had experienced so many adventures in order to prepare a novel.

The most interesting and crucial point in these conversations is on Page 18 that Greene confesses a change in himself:

"Don't go asking me to explain myself. I don't know myself, and I don't want to. Don't try to trap me with some sentences. I wrote thirty to fifty years ago expecting me to think the same way today. I am, remember, someone who changes. Each year I feel different."(p.18)

The last sentence of this statement can be considered as the climax of this conversation and even Graham Greene's life. He obviously confesses that he has changed and this can be applied to the study of his novels and the change in their contents. But as Greene himself says in this interview it is not correct to tell that Greene has changed and become a different person, he has just got a new vision about life and humanity.

The phrase ' dangerous edge of things' is defined by Greene as the narrow boundary between loyalty and disloyalty, between fidelity and infidelity, the mind's contradictions, the paradox one carries within oneself. This has always been present in Greene's novels, always the characters feel themselves in the dangerous edge of things and this makes them to act based on their logic not their beliefs.

Greene in his conversation has discussed the' rootlessness'. He confesses that rootlessness is his subject and he also believes that on the human plane there have been plenty of failures and he justifies his failures and lapses.

He explains his uncomfortable feelings about himself: 
"I've betrayed a great number of things and people in the course of my life, which probably explains this uncomfortable feeling I have about myself, this sense of having been cruel, unjust. It still torments me often enough before I go to sleep"(p.20)

These lines shows the reason for Greene's uneasiness about himself. And maybe because of this he says that he doesn't know himself.

Another interesting point about Greene is his use of mea culpa instead of "hell", and to answer Marrie's question " Are you afraid of Hell?"

" No, I don't believe in it. I believe, rather in a sort of purgatory."

What is Purgatory?

" It's what we- you and I - are living through at this moment."

So it is clear that why we encounter such dichotomy in Greene's novels.

Escape from himself which is obvious in so many of Greene's works is also discussed here. He always tries to escape from himself. He has another character that believes others must discover not himself. He believes in the existence of a pattern in every writers works that is better be discovered by critics.

In this book the tension in Greene's childhood is also obvious. He openly talks about his time in boarding school and its effects on his life. It had caused a kind of ' Divided loyalty' in his life and work. Before going to Boarding School Graham felt so happy and enjoyed his life. There he felt a kind of 'duality'.

But the state of real Boredom as Greene puts it:

"the poignant feeling existing in my works comes from my adolescence, between thirteen and sixteen, when I started trying to escape from myself. It's all bound up with boredom, I think. Boredom started in me pinging when I was about sixteen. It reached a point where I felt I had a balloon blowing up inside my head, ready to burst. It was something physical as well as mental..."(p. 31)

Between these conversations his feeling towards his parents is also distinguishable.

" I was very fond of her (his mother), though I realized that I could go happily for months without seeing her."

" I had no feelings about my father" (p. 32)

At the age of fourteen Greene had to go to psycho-analysis because of the conflicts and despair in school, about psycho analysis he says:

"Psycho- analysis awakened in me a keen interest in dreams and the work of the unconscious."

Another discussed point in this conversation is Greene's attempts to commit suicide. At one period in his life he started playing Russian Roulette, in order to make himself understand the value of life better. He has committed suicide because of boredom and despair which bothered him in life. But after trying Russian Roulette for so many times he became tired of this too and didn't continue. The idea of suicide is present in so many of Greene's novels. Characters bored of life and its repetitiveness try to kill themselves and make others happy by their death.

Graham Greene was also a great journalist. It may be because of his travels to a lot of countries. He traveled to so many countries and took notes, he mostly loved Africa. Even in his novels the effect of these travels is obvious. These travels consist the background of so many of his novels. The people, cities, cultures and every detail of these countries are presented in his novels.

As Marrie states

"Graham Greene the journalist, the 'explorer', the adventurer, never disarms Graham Greene the writer: he remains too much attached to his obsessions, for him writing is a form of action."

Curious and adventurous were two adjectives which described Greene best. He loved travelling and finding new cultures, new friends, and feeling new experiences. He has confessed using opium while writing his works. He tells that using opium had helped him stay awake at nights and travel. He had described about one of his experiences in which he had used opium in order to stay awake at nights and write a novel that he needed its money a lot. He has also been accused of having relationships with so many women except his wife. Because of this he always considered himself to be a bad husband.

When Greene is asked about the sense of anguish present in his novels his answer is :

"I'm not conscious of it. I don't go out of my ways to communicate it to the reader. How do you expect one to be able to notice a trait which is so much a part of daily life? I can capture anguish when certain characters betray it, at certain points in a novel, but I don't recognize it as a constant in my books... I don't want to be confronted with the pattern in the carpet..." (Conversations p. 140)

\section{Conclusion}

To conclude the theses it is good to point to what Mark Bosco. S. J. has concluded about Greene's dichotomy in his book "Graham Greene's Catholic Imagination" (2005). 


\section{He writes:}

"I have traced the influences on Greene's religious imagination, correlating his own explicit references to theologians and catholic artists, ..., Greene never liked being called a Catholic novelist; he was more comfortable with the title" Christian humanist". His fiction like all good literature, tended to encourage readers to acknowledge and attend to the humanity of other human beings, to enter a fictional world in order to experience "the heart of the matter" about human life or "the human factor" in the mystery of political events." (p. 156)

Then he states the idea of so many critics that has said Greene become more secularized later in his life, arguing that his late novels reduce religious belief to such an extent that only the aura of belief remains. He rejects this argument about Greene and instead states his own idea that:

"Greene jus reduced the institutional and rationalized side of Catholic belief, not to rid himself of it, but to make it clear that it is the practice of faith, hope, and love,--- and primarily a faith, hope, and love that costs the individual something--- that makes possible belief in a God present in the world. The whiskey priest, Father Rivas, and Monsignor Quixote lose the institutional trappings of their priesthood in order to gain participation in the drama of Christ's suffering." (p. 157)

But on page 72 of the same book Bosco(2005) states that:

“The Quiet American (1955), Our Man in Havana(1958), A Burnt Out Case (1961), The Comedians (1966), and Travels with my Aunt (1969) lacked the religious intensity of his earlier ones. Part of the reason is that Greene's own Catholic fervor lessened during these decades, due in no small part to the psychological trauma of ending his relationship with Walston."

As it was studied in this study, most of Greene's characters were Catholics who mostly disobeyed the rules of the Catholic Church. Although they were Catholics, they committed crimes and rebelled the doctrines not to show that they don't believe in God, but to show that it is in practice and action that someone's faith is revealed. As Bosco (2005) puts it:

"The presence of God is to be found in the fallen nature of Greene's characters."

Greene himself explains a lot about such a duality in his works he states that such a duality is the cause of his experiences in the Berkhamested School where his loyalty was divided between his father and school friends. This and such other experiences like travelling to many countries and observing their difficulties and their power to overpass the problems made Greene to write mostly about the sinners, or the people in the "dangerous edge of things".

As it was told before, Graham Greene has been accused of changing his view points from religious to more secularized ideas, but in his conversations with Allain-Marrie he states that:

"Don't go thinking as many others have done, that I've undergone some evolution from religion towards politics... for some years now there's been a preponderance of novels with a political flavor, but religion still interests me as much as ever." (p. 87)

And in another page of the same book he clearly states his idea that:

"For me, the sinner and the saint can meet; there is no discontinuity, no rupture. I believe in reversibility."

Besides the existing relationship between Greene's life and his works that was clear throughout this study Graham Greene from the first novels sympathized with evil characters such as Pinkie in the Brighton Rock who although he was a Catholic he committed sin and Greene had hope for his salvation, and like Scobie in The Heart of the Matter who committed sin but according to the priest there was a hope for his salvation even after committing suicide. But it is also clear that during his life he has changed his ideas and he himself has confessed that no one can have same ideas during his/her lifetime. As it was clear in this study in his first novels Greene discussed the evil and good, right and wrong, hell and heaven and mortal sin, but in his last novels these discussions become less and less and he concerns mostly political and social aspects of life.

In his letters Greene at first wrote with a lot of enthusiasm and passion about his love to Vivien and his interest to become a Roman Catholic, but in his letters in the old times he confesses that he even does not attends The Communion, and also he doesn't see this anymore necessary.

In his conversations also he has many times referred to his belief and his faith, the clear diagnosis on the writers part can solve the dichotomy existing in his works, he believed that belief is something rational and faith something Godgiven, whenever you had problem believing in something faith could help you and make you overpass your doubt.

So this theses as a biographical study of Graham Greene proved the close relationships existing between writer and his works, all his works were his experiences during his travels, his personal dilemmas, his childhood difficulties, his love and religious experiences, and so many other experiences which influenced Greene's writing, and also proved that Greene's ideology and the way of thinking has undergone a change, but the traces of his humanist Catholicism were present in his earlier works, and some events such as his love to his future wife, the publication of some special books such as Brighton Rock made his fame as a Catholic writer. Even Greene himself rejected being called a Catholic writer.

So it is obvious that it is not important if a priest has child, a Catholic committees suicide, kills another human being, or does not attend the Catholic ceremonies, the important point in his idea is that these people had done something useful to human beings and God is that much kind that all these people are going to be saved. 
Another reason for the change in Graham Greene's thought can be Second Vatican Council. Graham Greene's revival coincided with this event. The Church was beginning to renew its rules, its doctrines and etc. and Greene couldn't be unaware about such changes. This movement aimed to make relationship between modern world and the Church; it couldn't any more rely on the previous doctrines and rules, so it began to make new changes even to the Church. Bosco(2005) describes this movement as this:

" If Catholicism had in past stressed a vertical relationship between God and the human person, the new impetus of the Council was to imagine Catholicism in horizontal relationships that saw religious faith as affecting the social, political, intellectual, and scientific discourses of the period. Engaging atheism and secular humanism became a central concern of the Council."

Greene not only forgot religion at his late novels, but also concerned himself more with Catholicism and its new dimensions. So it is not true to say that Greene forgot religion and just cared about politics. He discovered new aspects of faith and belief.

Another critic concludes studying Greene's Catholic novels as the following:

"The analysis of the narrative representation of God in Graham Greene's Catholic novels shows that Greene employs new narrative ways of addressing himself to the reader... Greene's novels do not prove God's existence to the reader by omniscient narration displaying a speaking, present God's providential intervention. Like the new French Catholic novels of the interwar and post war period, Greene's novels invite the reader to choose a religious interpretation which is not guaranteed as the only truth by the narrator."

As it was clear in Greene's novels the last sentence" choose a religious interpretation which is not guaranteed as the only truth by the narrator", was completely observable. The novels were open ended and the reader himself/herself is going to choose whether the sinner is forgiven or not? Even the priests, the saints, and most religious people in Greene's novels do not announce the only truth, and they do not even judge about the sinners' destiny. So each reader is free to decide and judge if the sinner can be forgiven by God or not. The Salvation of sinners cannot be decided.

\section{References}

Atkins, J. (1966). Graham Greene. London: Cadler and Boyars.

BOSCO. S.J., M. (2005). Graham Greene's Catholic Imagination. New York: Oxford University Press.

Brennan, M. (2010). Graham Greene Fiction, Faith and, Authorship. New York: NY 10038.

F.Cummings, O. (2003). The Grace of Graham Greene. Oregon, Mount Angel Seminary.

Greene, G. (1977). Brighton Rock. New York: Penguin.

Greene, G. (1978). The Heart of the Matter. New York: Penguin.

Greene, G. (1990). The Quiet American. New York: Penguin, Viking.

Greene, G. (1980). Ways of Escape. New York: Simon and Scluster.

Greene, R. (2007). A Life in Letters. London: Clays Ltd, St Ives plc.

Hoskins, R. (1999). Graham Greene an Approach to the Novels. New York: Garland Publishing.

Loddegaard, A. (2008). The Silence of God in the Modern Catholic Novel. Forum on Public Policy.

Marie-Francoise,A. (1984). The Other Man: Conversations with Graham Greene. New York, Penguin Books.

Pryce-Jones, D. (1963). Graham Greene. London: Oliver and Boyd.

Roston, M. (2006). Graham Greene's Narrative Strategies, A Study of Major Novels. New York: Palgrave Macmillan.

Sinyard, N. (2003). Graham Greene: A Literary Life. New York: Palgrave Macmillan Publication. 